\title{
Industrial Sector Performance and Poverty Reduction in Nigeria: 1981-2018
}

\author{
Eneji Mathias Agri ${ }^{1,2^{*}}$, Tangka Job Gonya ${ }^{1}$, Eneji Angela Iyaji ${ }^{3}$, Haruna Habila ${ }^{1}$, Uzochukwu \\ Patience Chidiebere ${ }^{1}$ \\ ${ }^{I}$ Department of Economics, University of Jos \\ ${ }^{2}$ Senior Research Fellow, China-Africa Science and Technology Foundation, Beijing \\ ${ }^{3}$ Department of Business Administration, University of Jos
}

*Corresponding Author: Eneji Mathias Agri, Department of Economics, University of Jos \& Senior Research Fellow. China-Africa Science and Technologv Foundation. Beiiing

\begin{abstract}
The study empirically examined industrial sector performance and poverty reduction in Nigeria and time series data were sourced from different sources spanning from 1981-2018. Econometric techniques, stationary unit test (ADF), Johansen Co-integration test, and techniques of Granger causality test, Ordinary Least Square (OLS) and multiple regressions were employed in the study. The regression estimated result revealed that aggregate industrial output (INDQ) had positive impact on poverty reduction in Nigeria so also aggregate industrial employment (INDEM). The coefficients of the estimated results were; POVR = $49.14225+2.00 E-06 I N D Q+1.58 E-06 I N D E M$ and the $R 2=63.34 \%$. From the result of the Granger causality test, the study revealed that aggregate industrial output (INDQ) granger caused poverty rate $(P O V R)$, poverty rate (POVR) granger caused aggregate industrial employment (INDEM), and aggregate industrial output (INDQ) granger caused aggregate industrial employment (INDEM) all depicting a unidirectional causality. The study recommends that the government of Nigeria should put in place the needed mechanism to ensure that budget allocation to industrial sector is increased for adequate industrialization for a purposeful increase in Gross Domestic Product (GDP) via increase in industrial output. Government poverty reduction strategies should be strengthened and financed adequately with proper coordination to ensure that funds are not misappropriated or diverted by government officials. The government should be proactive in terms of industrial policy consistency and continuity to make sure that uncompleted industrial projects are funded and monitored for proper industrialization. Technological development in the Nigerian industrial sector should be taken with utmost seriousness by the government, in partnership with the private sector, to address squarely the challenges of obsolete technologies which are counterproductive.
\end{abstract}

Keywords: Industrial Performance, Poverty Reduction, Industrial Output, Industrial Policy, Manufacturing.

\section{INTRODUCTION}

The structure of the Nigerian economy at independence in 1960 was that of providing agricultural raw materials needs of the advanced economies, particularly of Britain. The bulk of national income was from exports of primary agricultural products. The level of industrial activities in the country was very low and, mostly commercial activities owned and run by multinationals. These companies engaged in trade and commerce especially in the importation and distribution of manufactured goods. Laying a solid foundation for the development of an industrial economy for Nigeria was not part of the colonial economic policy, (Egwaikhide, 2001 and Banjoko, 2012).

Industrialization which is a deliberate and sustained application and combination of an appropriate technology, infrastructure managerial expertise and other important resources has attracted considerable interest in research (Okafo, 2005).

Industrialization involves activities in craft, mining, processing, and manufacturing, greater emphasis is given to manufacturing, construction and mining.

It seems that the level of abject poverty in Nigeria is due to lack of proper attention or failure to industrialise the country, which informed this study. 
Staggering poverty in the midst of plenty is one of the world's unsolved issues especially in the developing countries. Poverty has multi-dimensional nature and can be evident in different forms such as deficiency of material income adequate to guarantee good standard of living; unemployment, dependency on imports, inflation, hunger and under-nutrition; illness; limited education and fundamental services; persistent rise in mortality and morbidity due to sickness; homelessness and insufficient housing; insecure environments and social exclusion and discrimination (Ogbeide, NwamakaandAgu, 2015). Poverty kills about 25000 children each day especially in some of the poorest countries on earth. About 2.8 billion of the world population lives on less than $\$ 2$ daily and about 1.4 billion live on $\$ 1.9$ per day (World Bank, 2016).

\section{Statement of the Problem}

Nigeo.ria has laid so much emphasis on industrialization since independence in 1960, yet the country is not industrialized as at 2020, and may not be industrialize as at 2040. A lot of efforts have been put into the industrialization process. Plan after plan, investment policies have been renewed, fine-tuned and at times completely revamped. Resources are abundant and investment opportunities are almost unlimited yet poverty rates have been on the increase in Nigeria. Various industrial development policies, perspective plans and medium-term economic plans, the $4^{\text {th }}$ development Plan acknowledged that manufacturing is capable of sustaining a minimum growth rate of $15 \%$ per annum, contributing over 7\% to gross domestic product there by reducing poverty, yet by 2019 Nigeria has the highest number of people living below the poverty line.

The history of industrial development in Nigeria is a classic illustration of how a nation could neglect a vital sector through policy inconsistencies and distractions attributable to the discovery of oil (Adeola, 2005; Ewubare and Okpanni, 2018). President Buhari in 2018 decried the pathetic state of the industrial sector, stating that Nigeria has become a marketer of other countries' merchandise; there is need for us to produce what we eat and use what we produce.

The more recent experiences of the East and Southeast Asian economic transformations demonstrate that diversification into manufacturing and industrial production are critical to poverty reduction. This is the gap that is yet to be filled in Nigeria. It is in the light of the foregoing that this study seeks to evaluate the industrial sector performance and its impact on poverty reduction in Nigeria. The study therefore seeks to answer the following research questions:

\section{RESEARCH QUESTIONS}

1. To what extent have the industrial output impacted on poverty reduction in Nigeria?

2. What is the causal relationship between aggregate industrial output, aggregate industrial employment and poverty rate in Nigeria?

3. What is the nature of the trends of aggregate industrial output, aggregate industrial employment and poverty rate in Nigeria?

4. What are the challenges that impede industrial sector performance in Nigeria?

\section{OBJECTIVES OF THE STUDY}

1. To determine the extent to which industrial output have impacted on poverty reduction in Nigeria.

2. To find out the causal relationships between aggregate industrial output, aggregate industrial employment and poverty rate in Nigeria?

3. To establish the nature of the trends of aggregate industrial output, aggregate industrial employment and poverty rate in Nigeria?

4. To examine the challenges that impede on industrial sector performance in Nigeria.

\section{LITERATURE REVIEW}

Industrialization is the process of building up a country's capacity to produce varieties of goods and services- extraction of raw materials and manufacturing of semi-finished and finished goods. Anyanwu, Oyefusi, ,Oaikhenan and Dimowo (1997), describes industrialization as the process of building up a nation's capacity to convert raw materials and other inputs to finished products and to manufacture goods for further production or for final consumption. Industrialization enhances the 
utilization of productive inputs (labour, capital and raw materials), given the country's technology, to produce non-durable and durable consumer goods, intermediate goods and capital goods for domestic consumption, export or further production. Thus industrialization could be described as the process of transforming raw materials, with the aid of human resources and capital goods into

(a) Consumer goods, (b) New capital goods which allows more consumers goods (including food) to be produced with the same human resources, and (c) Social overhead capital, which together with human resources provide new services to both individuals and businesses (Ekpo, 2005).

Kirkpatrick (1985), posited that industrialization involves a number of changes in economic structure of a country such as a rise in the relative importance of manufacturing industry; a change in the composition of industrial output; and changes in production techniques and sources of supply for individual commodities. Industrialization is, indeed, a wide concept. Broadly conceived, it relates to development in many industries/sectors such as manufacturing, banking, building/construction, mining/quarrying, communication, real estate (Obioma and Ozughalu, 2005) and public utilities (Ekpo, 2005). CBN (2002), gives the components of industrial sector in Nigeria to include the manufacturing, construction, electricity, mining, water and gas industries. On the other hand, industrial policy, broadly defined is all forms of state intervention that affect and influence industrial activities (Foreman-Peck \& Federico, 1999; Busari, 2005).

The United Nations fundamentally see poverty as a denial of choices and opportunities, a violation of human dignity. It means lack of basic capacity to participate effectively in society. It means not having enough to feed and clothe a family, not having a school or clinic to go, not having the land in which to grow ones food or job to earn one's living, not having access to credit. It means insecurity, powerlessness and exclusion of individuals, households and communities. It means susceptibility to violence, and it often implies living in marginal or fragile environments, without access to clean water or sanitation. The provision of these basic necessities implies poverty reduction, which in the context of this study, seems to have correlation with industrial performance.

According to the World Bank, (1996), poverty is pronounced deprivation in well-being, and comprises many dimensions. It includes low incomes and the inability to acquire the basic goods and services necessary for survival with dignity. Furthermore, the World Bank see poverty encompassing low levels of health and education, poor access to clean water and sanitation, inadequate physical security, lack of voice and insufficient capacity and opportunity to better our lives. Poverty connotes many things i.e. lack of material well-being, insecurity, low self-confidence, psychological distress, unpredictability, lack of freedom of choice and action and inability to believe in one self (Narayan, 2000).

Poverty reduction in the context of this study refers to the enhancement of opportunity for people living in absolute poverty through the index of industrial production, industrial output, industrial employment, industrial income and consumption of industrial goods and services. Industrialization implies moving out of less productive sector (primitive agriculture) where poverty rates are often much higher, to more productive sector (manufacturing) may also relieve some of the pressures put on agricultural land and have some direct poverty reducing effect through raising agricultural incomes. Such changes in the structure of employment and income can have very large effects on poverty, as it may enable people to escape poverty traps.

Several empirical studies have supported the assertion of the existence of a relation between industrialization and economic growth hence poverty reduction in several economies of the world. For instance, Ebong, Udoh and Obafemi (2014), using time series for five decades (1960-2010) based on the Eagle-Granger two steps and Johansen co-integration test, and the vector auto regression technique studied globalization and industrial development in Nigeria. Findings clearly showed that globalization had significant impact on industrial development. They suggested that increasing the level of trade with the rest of the world would create opportunities to export local raw materials and import necessary input into the industrial process and that financial liberalization enhances industrial development. Hence, they recommended that policies are required to reserve the tide of capital flight from the country and channel resources toward the industrial sector.

Likewise, Ogunrinola and Osabuohien (2010) examined the impact of globalization on employment generation in Nigeria's manufacturing sector using ordinary least square technique of analysis on a time series data for the period of 1990-2006 and discovered that globalization has a positive impact on 
employment level in the Nigerian manufacturing sector. On another study that relates to the developing economies conducted by Kaya (2010) which investigated the effect of the latest wave of economic globalization on manufacturing and employment in developing countries with the use of a comprehensive dataset on 64 developing countries from 1980-2003. The study is concerned with classic debate on the benefits of industrialization and how this affects developing countries. The results generally demonstrate that manufacturing employment increased in most developing countries. First, this study finds that the level of economic development measured by GDP per capita is the most important factor influencing the size of manufacturing employment. Second, economic globalization also influences manufacturing employment in developing countries but mainly through trade.

From another line of thinking, Ndiyo and Obongi(2003) with the use of the vector autoregressive technique of analysis examined the challenges of openness in developing countries for lessons to be drawn using Nigeria from (1970-2000). Empirical result from this study shows that globalization has had both positive and negative effect on the Nigerian economy. The negative effect according to Mike (2012) includes the challenges for industrial policies in Nigeria which are powerful tools to promote rapid economic growth and development. He observed that Nigeria has not been able to make appreciable progress in industrial development due mainly to policy failure. He stated that different governments since independence have been trying out different approaches based on the dictates of those in power and those who advise them, stressing that the result has been policy summersault and inconsistency favouring rent seeking.

Also Gylych and Enwerem (2016) in their study, the impact of industrialization on economic growth: experience of ten countries in ECOWAS between the periods of (2000-2013), revealed that industrialization has had a negative impact on economic growth in Nigeria in the long run. The methodology adopted was the Ordinary least square (OLS) technique. The study recommended that government should redirect its industrial and investment policy so as to increase output of real gross domestic production (RGDP), flexible exchange rate and control inflation rate since their findings showed increase in exchange and inflation rate, decreased output. Also industrial and investment policy should be flexible on infant industries so as to encourage productivity and improve GDP.

A study by Isiksal and Chimezie (2016) indicated that no country particularly the developing ones has attained a level of economic growth without sub-sector linkage. They evaluated the Impact of Industrialization on Nigeria from 1997-2012 using the Johansen co-integration testing approach which demonstrated a significant long-run relationship between the three variables used. The results reveal that agriculture, industry and services have a significant positive relationship with GDP.

Rodrik (2006) emphasizes that episodes of growth acceleration are often associated with an increasing role of manufacturing in the economy. Szirmaia and Verspagen (2015) analysed the importance of manufacturing as a driver of economic growth using data for 88 countries ( 21 advanced economies and 67 developing countries) over the period 1950-2005. They report that manufacturing has a positive impact on economic growth.

\section{THEORETICAL FRAMEWORK}

\subsection{Keynesian Theory And Poverty}

Keynesians suggest that growth can promote economic development and thus relieve poverty, hence further justifying government intervention at the macroeconomic level (via fiscal and monetary policy), mainly to tackle involuntary unemployment. The intervention of government also include the provision of capital and public goods, otherwise referred to as socioeconomic expenditure of government (Sachs, 2005). T he main signs of underdevelopment in a country or region include: poor levels of human capital (health, skills and education), business capital (machinery and buildings), infrastructure (transport, power and sanitation), natural capital (viable land), public institutional capital (rule of law and security) and knowledge capital (technical know-how needed to raise productivity). For example, this view involves a focus on the provision of capital goods, in the form of education (to increase human capital) and infrastructure (to increase productive capacity), flowing to the poor, as well as overall development of markets that may be applicable. Sachs' approach is innovative in being "clinical" in designing anti-poverty intervention and needing to adapt to circumstances rather than "one size fits all". Economies, like persons, should be seen as complex systems, where failures in one part (e.g. corruption) lead to failure elsewhere (e.g. market systems), and "diseases" differ (Davis, 2007). Factors to be taken into account include the existence of a 
poverty trap, the economic policy framework, the fiscal framework and fiscal traps, physical geography, governance patterns and failures, cultural barriers and geopolitics. In this regard, poverty in a given country might be heavily affected by the presence of a very weak institutional environment including corruption, for example, which adversely influences the functioning of markets, whereas in another context the most crucial factor may be geographical isolation, which may impede the import of basic goods and services needed for individuals to attain a certain level of well-being. Hence, under this view, the importance of these wide ranges of factors at the macro level needs to be weighed in each specific case, and only then can a particular, tailor-made policy agenda be designed to combat poverty. Critics (as summarised in Davis, 2007) argue that the Sachs approach resembles the "big push" to get the poor out of a poverty trap by massive aid that was fashionable in the 1950s but shows little evidence of having worked. Perhaps the approach should be more "bottom up" from the poor rather than "top down" to them. Black markets might arise in the capital-good commodities he proposes to distribute. Much more rigorous ways of preventing abuse of aid by governments may need to be devised as argued by (Lal, 1995)).

\subsection{Endogenous Growth Theory}

Endogenous growth theory is a theory which explains the long-run growth rate of the economy on the bases of endogenous factors against the exogenous factors of the neoclassical growth theory. The endogenous growth models have been developed by Arrow, Romer and Lucas, among other economists. The theory holds that economic growth is primarily the result of endogenous and not the external forces. Endogenous theory holds that investment in human capital; innovation and knowledge are significant contributors of economic growth. The theory also focuses on positive externalities and spill over effects of knowledge based which will lead to economic development.

The theory believes that improvements in productivity can be link to faster space of innovation and extra investment in human capital. The endogenous growth theory also holds that policy measures can have an impact on the long-run growth rate of the economy (Rebelo, 1999). The model is one in which the long-run growth rate is determined by variables within the model, not an exogenous rate of technological progress as in neoclassical growth model. Romer (1994) asserts that: Model of endogenous technical change of 1990 identifies a research sector specializing in the production of ideas. This sector invokes human capital along with the existing stock of knowledge to produce a new knowledge. To him, ideas are more important than natural resources endowment. He cited the example of Japan which has few natural resources but was open to new western ideas and technology. It imported machines from the United States, dismantled them to see how they worked and manufactured their better prototypes.

There is central knowledge in this theory as a major determinant of economic growth. Endogenous growth theory predicts positive externalities and spill over effect from a development of high valueadded knowledge economy which is able to develop and maintain a competitive advantage in growth of industries in the global economy.

\section{Methodology}

The research methodology combines both empirical and theoretical analysis of data. Ordinary Least Square (OLS) technique is adopted for data analysis. The choice of this technique is informed by the time series characteristics of data proxied for industrial performance and poverty reduction. This study generates secondary data on Poverty Rate (POVR), Manufacturing output (MANQ), Mining output (MINQ), Construction output (CONQ) and Employment Rate (EMPR). The data collected covered the period of 37 years (1981-2018). The data used were logged in order to have the common basis among the variables and to provide reliable economic interpretation of the results.

The unit root test was conducted in order to have stationarity of the data and to avoid misleading result. The result of the unit root test justified the adoption of multiple regression method. The Ordinary Least Square multiple regression model is estimated with the aid of econometric software (e-views version 10) to determine the relationship between industrial sector performance and poverty reduction in Nigeria. The Granger causality test is conducted to identify the causal relationship between poverty reduction and industrial output in Nigeria and also the causal relationship between industrial performance and employment rate in Nigeria. 


\subsection{Model Specification}

The econometric methodology procedure included the specification of both the mathematical and econometric models, (Gujarati, 2004). The mathematical function of the model is specified as:

$\mathrm{POVR}=\mathrm{f}(\mathrm{INDQ}, \mathrm{INDEM}$,

Where:

POVR = Aggregate Poverty Rate (Proxy for poverty reduction)

INDQ = Aggregate Industrial Output

INDEM = Aggregate Industrial Employment

Industrial sector performance is proxy by INDQ and INDEM.

Aggregate Poverty Rate (POVR) is the dependent variable while the control variables are; Aggregate Industrial Output (INDQ) which comprised of manufacturing output, mining output, construction output) and Aggregate Industrial Employment (INDEM). The mathematical function of the model is transformed into econometric functions as:

POVR $=\beta_{0}-\beta_{1}$ INDQ $-\beta_{2}$ INDEM $+\mu-$

The negative sign is apriori expectation of INDQ and INDEM on poverty reduction.

$\operatorname{LogPOVR}=\beta_{0}-\beta_{1} \operatorname{LogINDQ}-\beta_{2} \operatorname{LogINDEM}+\mu$

Meanwhile, natural logarithm is introduced in the equation to bring the variables to common base since they are not in the same unit. Where: $\beta_{0}=$ the constant, $\beta_{1}$, and $\beta_{2}$ are the coefficients of the explanatory variables and $\mu=$ disturbance term. Theoretically, the coefficients are expected to take these signs: $\beta_{0}>0, \beta_{1}<0, \beta_{2}<0$. Note that: $\beta_{0}=$ the constant, $\beta_{1}=$ coefficient of aggregate industrial output (INDQ), $\beta_{2}=$ coefficient of aggregate industrial employment and $\mu=$ disturbance term.

\subsection{Estimation Results}

The data for all the estimation are presented in the appendix.

\subsection{Unit Root Test}

The unit root test is usually used to examine the properties of the variables of any given model. It is used to check for the presence of unit root that is, non-stationarity of the variables. This test is carried out using Augment Dickey-Fuller (ADF) test. The Unit root test is also known as co-integration test. The results from the test are tabulated below.

Table1. Result of Stationary Test

\begin{tabular}{|l|l|l|l|l|}
\hline Variables & $\begin{array}{l}\text { ADF Test Statistic } \\
\text { Value }\end{array}$ & $\begin{array}{l}\text { Mackinnon Value } \\
\mathbf{( 5 \% )}\end{array}$ & $\begin{array}{l}\text { Order } \\
\text { Integration }\end{array}$ & of \\
\hline LogPOVR & -3.614893 & -2.945842 & $1(1)$ & Stationary \\
\hline LogINDQ & -6.728306 & -2.945842 & $1(1)$ & Stationary \\
\hline LogINDEM & -5.960073 & -2.945842 & $1(1)$ & Stationary \\
\hline
\end{tabular}

Source: Computed with e-views 10 by the researcher (2020)

From the result all the variables; Aggregate Poverty Rate (POVR), Aggregate Industrial Output (INDQ) and Aggregate Industrial Employment (INDEM) met the apriori expectation at first difference. In other words they are integrated of order one. The need to conduct co-integration test to check whether the control variables have long-run relationship with the dependent variable becomes necessary.

\subsection{Johansen Co integration Test}

The co-integration test is used to check for long-run relationship between the dependent and independent variables (OgundipeandAworinfe, 2013). The co-integration test was carried out using the Johansen technique also using E-views software package and it produced the result shown in the table 3 . 
Table2. Johansen Co-integration Test Using Trace Statistic and Max-Eigen Value

\begin{tabular}{|l|l|l|l|l|}
\hline Eigen-Value & $\begin{array}{l}\text { Hypothesized } \\
\text { No. of CE(S) }\end{array}$ & Trace Statistic & Max-Eigen Statistic & $\begin{array}{l}\text { Hypothesized } \\
\text { No. of CE(S) }\end{array}$ \\
\hline 0.340314 & None* & 20.96912 & 14.97578 & None * \\
\hline 0.124275 & At most 1* & 5.993344 & 4.777327 & At most $1^{*}$ \\
\hline 0.033214 & At most 2 & 1.216017 & 1.216017 & At most 2 \\
\hline
\end{tabular}

Source: Computed with e-views 10 by the researcher (2020)

From the model POVR $=\mathrm{f}$ (INNQ, INDEM), the co-integration test result in table 3 shows that there is a long run relationship between the variables in the study: Aggregate Poverty Rate (POVR), Aggregate Industrial Output (INDQ) and Aggregate Industrial Employment (INDEM). The Trace test shows that there are two (2) co-integration equations and the maximum eigen value test also shows evidence of two co-integration equations. Both tests are carried out at 0.05 per cent level.

\subsection{Granger Causality Test}

According to Engle and Granger (1987), causality test is used to test the causal relationship between variables in order to ascertain which of the variables affect the other and also to know the direction of the causality (unidirectional or bidirectional or no causal relationship). The use of Granger causality test for this study is justified for the investigation of the causal relationships between industrial performance (proxy by industrial output and industrial employment) and poverty reduction (proxy by the aggregate poverty rate) in Nigeria. The result of the Pairwise Granger causality test is shown in table 5 .

\begin{tabular}{|c|c|c|c|c|}
\hline \multicolumn{5}{|l|}{ Table 3:Pairwise Granger Causality Tests } \\
\hline \multicolumn{5}{|l|}{ Date: 04/22/20 Time: 08:14 } \\
\hline \multicolumn{5}{|l|}{ Sample: 138} \\
\hline \multicolumn{5}{|l|}{ Lags: 2} \\
\hline \multicolumn{2}{|l|}{ Null Hypothesis: } & Obs & F-Statistic & Prob. \\
\hline \multicolumn{2}{|l|}{ INDEM does not Granger Cause POVR } & 36 & 0.04461 & 0.9564 \\
\hline \multicolumn{3}{|l|}{ POVR does not Granger Cause INDEM } & 5.87133 & 0.0069 \\
\hline \multicolumn{2}{|l|}{ INDQ does not Granger Cause POVR } & 36 & 0.51436 & 0.6029 \\
\hline \multicolumn{3}{|l|}{ POVR does not Granger Cause INDQ } & 1.04535 & 0.3636 \\
\hline \multicolumn{2}{|l|}{ INDQ does not Granger Cause INDEM } & 36 & 5.78028 & 0.0074 \\
\hline \multicolumn{3}{|l|}{ INDEM does not Granger Cause INDQ } & 0.92065 & 0.4089 \\
\hline Null Hypothesis: & Obs & F-Statistic & Prob. & Causality \\
\hline $\begin{array}{l}\text { Log INDQ does not Granger Cause Log POVR } \\
\text { Log POVR does not Granger Cause Log INDQ }\end{array}$ & $\begin{array}{l}36 \\
36\end{array}$ & $\begin{array}{l}0.51436 \\
1.04535\end{array}$ & $\begin{array}{l}0.0209 \\
0.3636\end{array}$ & Unidirectional \\
\hline $\begin{array}{l}\text { Log INDEM does not Granger Cause Log POVR } \\
\text { Log POVR does not Granger Cause Log INDEM }\end{array}$ & $\begin{array}{l}36 \\
36\end{array}$ & $\begin{array}{l}.87133 \\
0.9564\end{array}$ & 0.0069 & Unidirectional \\
\hline $\begin{array}{l}\text { Log INDEM does not Granger Cause Log INDQ } \\
\text { Log INDQ does not Granger Cause Log INDEM5 }\end{array}$ & $\begin{array}{l}36 \\
36\end{array}$ & $\begin{array}{l}0.92065 \\
0.0074\end{array}$ & 0.4089 & Unidirectional \\
\hline
\end{tabular}

Source: Computed with e-views 10 by the researchers (2020)

Table4. Ordinary Least Square (OLS) Result.

\begin{tabular}{|c|c|c|c|c|}
\hline \multicolumn{5}{|c|}{ Dependent Variable: POVR } \\
\hline \multicolumn{5}{|c|}{ Method: Least Squares } \\
\hline \multicolumn{5}{|c|}{ Date: 04/22/20 Time: 07:45 } \\
\hline \multicolumn{5}{|c|}{ Sample: 1 38(1981-2018) } \\
\hline \multicolumn{5}{|c|}{ Included observations: 38} \\
\hline Variable & Coefficient & Std. Error & t-Statistic & Prob. \\
\hline $\mathrm{C}$ & 49.14225 & 2.394756 & 20.52078 & 0.0000 \\
\hline INDEM & $1.58 \mathrm{E}-06$ & $1.09 \mathrm{E}-06$ & 1.449963 & 0.1560 \\
\hline INDQ & $2.00 \mathrm{E}-06$ & $6.70 \mathrm{E}-07$ & 2.980925 & 0.0052 \\
\hline R-squared & 0.633395 & \multicolumn{2}{|c|}{ Mean dependent var } & 61.38158 \\
\hline Adjusted R-squared & 0.612446 & \multicolumn{2}{|c|}{ S.D. dependent var } & 17.79161 \\
\hline S.E. of regression & 11.07596 & \multicolumn{2}{|c|}{ Akaike info criterion } & 7.723087 \\
\hline Sum squared resid & 4293.690 & \multicolumn{2}{|c|}{ Schwarz criterion } & 7.852370 \\
\hline
\end{tabular}




\begin{tabular}{|c|c|c|c|}
\hline Log likelihood & -143.7387 & Hannan-Quinn criter. & 7.769085 \\
\hline F-statistic & 30.23532 & Durbin-Watson stat & 0.179688 \\
\hline Prob(F-statistic) & 0.000000 & & \\
\hline
\end{tabular}

Source: Computed with e-views 10 by the researchers (2020)

From the estimated result of the model APOV $=\mathrm{f}$ (INDQ, INDEM) as shown in table 6 above, the coefficient of the constant parameter is positive (49.14225) and is correctly signed. This is in consonance with the apriori expectation of a positive sign. This indicates that if all the explanatory variables are held constant, POVR will be 49.14225 and it signifies that the intercept of POVR is positive and by implication the percentage of the poor in Nigeria will be 49.1 per cent. The coefficient of INDQ is negative (-2.00E-06) and it is correctly signed and is statistically significant ( $\mathrm{t}-$ stat2.980925 > t-tab 2.015). This implies that one unit increase in INDQ will lead to 2.00 per cent decrease in POVR in Nigeria. The co-efficient of INDEM is negative (-1.58E-06) and is correctly signed. It is statistically significant because (t-stat $1.449963>t$-tab 2.015). This means that one unit increase in INDEM will lead to a 1.58 decrease in POVR within the study period.

The coefficient of determination $R$-Squared $\left(R^{2}=0.633395\right)$ which shows that about $63.34 \%$ of the variation in POVR is caused by industrial performance, proxy by changes in the explanatory or control variables (INDQ and INDEM). It means that $36.66 \%$ of the variation in the model unaccounted for is attributed to the error term and this shows that the line of fit is highly fitted. The Durbin-Watson statistic 0.179688 in table 5 is observed to be less than $\mathrm{R}^{2}=0.633395$ indicating that the model is not spurious. This revealed that there is no serial correlation in the model. The value of the probability of F-statistic is 0.000000 which is less than $0.05 \%$ level of significance, hence the null hypotheses of no significant impact of industrial performance on poverty rate in Nigeria are rejected and the alternate hypotheses are upheld.

\section{DisCuSSION OF RESEARCH FINDINGS}

The major indicators of poverty in Nigeria; lack of adequate food, shelter, education and health; vulnerabilities to ill health; economic dislocation; neglect by the government; and exclusion from key decision-making processes and resources in society. Poverty in Nigeria has been the result of economic, political, and industrial processes that interact with each other and frequently reinforce each other in ways that exacerbate the deprivation of the absolute poor. Poverty remains endemic in Nigeria despite the introduction of several industrial policies and anti-poverty programmes by successive governments. According to statistics, the incidence of poverty has significantly increased in Nigeria since 1980. The percentages of the Nigerian population that were classified as 'extremely poor' over the last three decades are as follows: 6.2\% (1980); 12.1\% (1985); 13.9\% (1992); 29.3\% (1996); 22.0\% (2004) and 38.7\% (2010). These increases are strongest among the most vulnerable groups. In 2012, for example, the National Bureau of Statistics (NBS) reported that the poverty crisis in Nigeria varied by region, sector and gender, and impacted Nigerian youth, children and mothers more than the adult male population.

Poverty levels in Nigeria vary widely across the country's geo-political zones where there are no industries. The proportions of the population in these zones that were 'food poor' in 2010 were: North-Central (38.1\%); North-East (51.5\%); North-West (51.8\%); South-East (41.0\%); South-South $(35.5 \%)$; and South-West (25.4\%).These statistics are reflections of poor industrial performance in Nigeria. The latter is caused by bad economic policies, inconsistencies and lack of harmonization and implementation of industrial policies over the decades.

This study uses the Textile Industry in particular to examine its impact on poverty Reduction. Nigeria had a prosperous textile industry till the mid 1980's. Before the structural adjustment program by the Babangida's government in 1985, the export of textile products and other manufactured exports in Nigeria was remarkable. The textile sector had an annual growth rate of 67 per cent. Its labour force in 1985 was 25 per cent of the manufacturing sector (NTMA 2009). The inability of the Nigerian textile industry to compete is chiefly due to its failure to produce at lower cost. The causes of the textile industry's decline are predominantly policy neglect, besides that, a range of local and global policy measures also contributed to the situation it is in today. Neo-liberal reforms and changing trade agreements, inadequate infrastructure for providing electricity and water, reduced cotton production and increased textile imports have all contributed to the industry's decline. 
The early independence years of the 1960s to the mid-1970s came to be known as the industrial development period aimed at converting abundant raw materials to manufactured goods. Encouraging retailers and wholesalers to convert and become manufacturers was the single most significant impetus to the growth of the textile industry in the country. 112 factories were involved in spinning, weaving and garment production by 1980 . The domestic manufacturing sector could have surged if not for the impediment experienced because of the introduction of Structural Adjustment Programmes in the mid-1980s. It is irrefutable that when right policies are implemented the textile sector has the potential to contribute to economic growth and poverty reduction in Nigeria.

Before 1985, the textile industry had become the largest employer of labour after the government. These factories have a direct 250,000 unionised workers, millions of cotton farmers as well as suppliers and traders (Aremu 2005). Direct employment afterwards declined to 175,233 in 1990, when the impact of SAP was full blown, 83,000 in 2000 and 21,000 in 2010 respectively. The industry's share of jobs and value addition was placed at 20 per cent in the mid 1980's. Textile and weaving apparel was the leading industry contributing 19 per cent of total consumer commodity industry employment in 1983. The textile industry is followed by beverages, food, as well as the tobacco industry (Brandell, 1991).Considerably; the industry's turnover has been placed at N8 billion per year. On replacement basis, the installed textile manufacturing capacity was set at N420 billion, and US $\$ 3$ billion investments in 1990 (UNIDO, 2003). With a population of over 180 million, Nigeria had the prospect of generating 1.2 billion meters of cloth per annum. When the ECOWAS subregional market is factored, Nigeria is a strategic textile location in the world. The industry can engage 3 million people. 26 out of the 36 Nigerian federating states grow cotton of long and short stable lengths. From this sound and solid context, the textile industry in Nigeria began to decline since the mid-1980s.

As Nigeria takes on more economic liberalisation, the manufacturing industries got weaken with a reduction in aggregate demand, which increases reckless imports, but dampens domestic production and manufacturing output. It also reduces the level of income and the level of employment, creating import-led unemployment. The oil price volatility, rapid decline in government revenues and expenditures have continuously reduced aggregate demand within the economy. It has created serious underutilisation of industrial capacity in the economy. Gross Domestic Product increased by only $1.3 \%$ with the annual population growth rate at $2.1 \%$. Aggregate index of industrial production declined by $5.1 \%$, which was more severe in the manufacturing sub-sector that fell by $8.1 \%$ as it contributed only $0.9 \%$ to the GDP from its $0.5 \%$ contribution of 1991 (CBN, 2000). The Central Bank of Nigeria in its annual statement for 1999 reported that the local textile industry suffered from cheaper foreign textile dumping and the sector recorded persistent output contraction or outright closure (CBN, 2000). As at April 2000, President Obasanjo observed that the characteristics of the Nigerian industrial sector include low capacity utilisation, which averages $30 \%$ in the last decade. The industrial sector had a low and declining contribution to national output, which averages $6 \%$ from 1997-1999. This contributed to declining growth rates; dominance of light assembly type consumer goods, low value-added production due to high import dependence for inputs and the prevalence of unviable state-owned enterprises. Overall, the fiscal narratives of the year 2000 showed that the country's economic performance was largely below average (OPS, 2001).

The long-standing constraints to manufacturing activities have not abated. Thus, the sector was still characterised by the crippling effects of past policy mistakes and undue competitive pressures due to the economic liberalisation policies of the country. 1985 was the most boisterous year in textile production with over $124 \mathrm{big}$, medium and small textile factories. By the year 2000 three years into the endorsement of the liberalisation policy, thirty-five textile factories closed down leaving behind 89 factories. Within the span of five years by 2005 the number of factories fell to 32 . The effect eventually manifested itself in continued unabated dumping reducing the factories to 25 and 16 in 2010 and 2015 respectively. Other challenges include reduction in capacity utilisation; absence of investment in the industry and the situation deteriorated by the day. The factories could not compete with comparatively affordable materials from East Asia. The challenge was further worsened by increased smuggling as the government did nothing to stop the illegal imports. There was also a problem of undeclared products and non-payment of duties even by legitimate importers. Nigerian market was flooded with imported textiles. Total textile imports into Nigeria were estimated at USD 1.7 billion most of which entered through porous borders. All these denied the local manufacturers the essential competitive advantage (NUTGWTN, 2005). The overall performance of the textile industry 
in Nigeria is in a state of crises. Average capacity utilisation rates fell from 79.7 percent in 1976 to an all-time low of 48.0 per cent in 2005 (CBN, 2005). By 2008, over 160 textile companies were closed. Capacity utilisation was estimated at less than $20 \%$ with ten factories employing barely 18,000 workers. Over two million Nigerians whose jobs were attached to the industry, such as traders, contractors, cotton farmers and the textile workers lost their means of livelihood due to the challenges facing the industry (Muhammad, 2011).

As of 2010, there were less than forty textile factories in Nigeria out of the close to 200 in existence formerly (Aremu, 2015). The distress closures caused in the communities where the factories were located are enormous. According to NUTGTWN (2005), more than one million persons whose means of livelihood are tied to the industry were adversely affected including traders and cotton farmers. The socio-economic consequences were colossal. With the fall of Kano, Kaduna and Lagos textile sector, imported textiles from China and other core trading partners from India, Indonesia and the UK dominated the market. In a way, textile manufacturing has returned to the condition it was in during colonial times in the 1950s when Nigeria imported finished textiles from the United Kingdom. Chinese textile companies and retail companies with foreign offices in Nigeria now distribute to local wholesale and also retail textiles directly to consumers.

\section{CONCLUSION}

The objective of the study was to empirically evaluate the industrial sector performance and poverty reduction in Nigeria. Nigeria's industrialization is state-driven and government has not been most effective in promoting industrialization in Nigeria. This s chiefly responsible for the poor performance of the Nigerian industrial sector for the period under review (1981-2018). Efforts to utilize Nigeria's immense natural resources for sustained industrialization and economic development were miserable failures. From 1991 after two decades of oil boom till dates, manufacturing subsector still contributes a declining less than 5 percent to Gross Domestic Product. Textile industry would have been an ideal import-substitution for Nigeria: there was demand for Nigeria's textile abroad, cotton was available, technological requirements was not overtly onerous, and textile tends to be a labour-intensive industry. However, politics, too early indigenization, poor quality of indigenous entrepreneurship, poor infrastructure, professional deficiencies, poor decision, poor management, reckless importation and competition from foreign firms in the industry have negatively affected the performance of Nigeria's textile industry. Generally, the failure of Nigeria to industrialize can be traced to politics and corruption where governments have squandered huge oil revenue, with illicit financial flows. Regional politics and corruption have prevented Nigeria from choosing the most economic solution to production and manufacturing problems. These have created an economy that is heavily dependent on imports and increased poverty rather than industrialization and poverty reduction.

Indeed, the role of industrial sector performance in poverty reduction in Nigeria is fundamental and cannot be over-emphasized amidst the challenges faced by the industrial sector. The sector has faced acute challenges such as; poor conception and implementation of industrialization strategies, technological backwardness, inadequate infrastructure, non-completion and functioning of industrial core projects due to inadequate budget allocation, corruption and misappropriation of funds meant for the development of industrial sector, inadequate trained personnel, poor maintenance of equipment, etc. This to a large extent has prevented the industrial sector from having in place the needed employment and increased level of production which would have led to poverty reduction and purposeful economic growth and development. Therefore, the study concludes that the Nigerian industrial sector has a luck-lustre performance and is yet to contribute significantly to poverty reduction in the country. However, aggregate industrial employment and aggregate industrial output are relevant mechanisms that can be used to reduce poverty.

The estimated regression result established a significant positive relationship between aggregate industrial output and poverty rate in Nigeria and likewise between aggregate industrial employment and poverty rate. This is contrary to apriori expectations. The study revealed through causality test that aggregate industrial output granger caused poverty rate, poverty rate granger caused aggregate industrial employment and also, aggregate industrial output granger caused aggregate industrial employment in Nigeria.

The trend analysis shows a relationship between aggregate industrial output and poverty rate and between aggregate industrial employment and poverty rate in Nigeria for the period under consideration. 


\section{RECOMMENDATIONS}

Based on the findings of this study, the following recommendations become necessary.

1. Industrial diversification, privatization, raising indigenous technology innovation through investment in research and development. Establishment of industrial and science parks and promotion of export processing zones (EPZ).

2. Government should ensure that budget allocations to industrial sector are actually utilized properly, increase the budget by at least 10 per cent for adequate industrialization. This will surely create employment opportunities, hence increase industrial output and reduce poverty in Nigeria. This can only be feasible when industrial tax rate is reduced at least by 2 per cent to encourage investment and industrial production at maximum level by both domestic and foreign investors. This implies that industrial tax structure should be reviewed to accommodate all and sundry in the industrial sector.

3. Government and the private sector should give maximum policy and financial support to small and medium scale enterprises (SMEs) which will spur industrialization in Nigeria. In addition, federal, state and local governments should implement policies that would make Nigeria's industrial sector less vulnerable to global economic forces, example, infant industries protection and local content development policies.

4. Government should be proactive in terms of industrial policy consistency and continuity to ensure steady increase in aggregate industrial employment. . There should be policy to check corruption and bad governance.

5. Government and the private sector should grant subsidy to owners of industries and also enforce the advancement of soft loans to prospective individuals and firms through the commercial banks and other credit worthy banks at low interest rate. At least interest rate charged on soft loans should not exceed 8 per cent and the funds should be made available once applied for. Credit availability will boost business transactions and hence economic activities will increase leading to improved industrial performance.

\section{REFERENCES}

[1] Adam, S (1776). "An Enquiry into the Nature and Causes of the Wealth of Nations", London: Methuen \& Co. Ltd.

[2] Adeoye, B. W (2005).Industrial Development in Nigeria in the Context of Globalization. In: The Challenge of Industrialization: A Pathway to Nigeria Becoming a Highly Industrialized Country in the Year 2015, Nigerian Economic Society, Ibadan.

[3] Alokan, O. O (2005).Theoretical Perspectives on Nigeria's Industrialization. In: The Challenges of Industrialization: A Pathway to Nigeria becoming a Highly Industrialized Country in the Year $2015 \mathrm{z}$ Nigeria Economic Society, Ibadan

[4] Amakom, U. (2012) Manufactured Exports in Sub-Saharan African Economies: Econometric Tests for the Learning by Exporting Hypothesis. American International Journal of Contemporary Research.Vol. (2) 4.

[5] Anyanwu, J. C., Oyefusi, A. \&Dimowo, F. A. (1997).The Structure not the Nigerian Economy. Onitsha, Nigeria: Joanee Education Publishers Ltd.

[6] Anyawu, J. C. (1997). "Poverty: Concepts, Measurement and Determination "Proceeding of NES Conference on Poverty Alleviation in Nigeria, Dept of Economics, University of Ibadan, Ibadan.

[7] Aremu, I. (2015). Reflections on Industry and Economy. Lagos: Malhouse Press Limited

[8] Aremu, I. 2005. End of (Textile) Industry? A Critical Study of the Collapse of Textile Industry in Nigeria and the Implications for Employment and Poverty Eradication. Lagos: Friedrich Ebert Stiftung

[9] Aremu, I. 2015. General Secretary, National Union of Textile, Garment and Tailoring Workers of Nigeria (NUTGTWN), Head Office, Textile House, Kaduna, Interviewer: M. Muhammad, PhD Fieldwork.

[10] Areola, F.A (2005). Productivity Performance in Developing Countries: A Case Study of Nigeria. United Nations Industrial Development Organization (UNIDO) Reports

[11] Asika, N. (2006). Research Methodology in the Behavioural Science, Lagos: Longman Publishers.

[12] Bamidele, R. O. (2005). "Globalization and the Nigerian Industrial Sector ".The Nigerian Journal of Economic and Social Studies, Vol. 47(2).

[13] Banerjee, A. \&Duflo, E. (2012). "Poor Economics: A Radical Rethinking of the Way to Fight Global Poverty “, Public Affairs, ISBN. 
[14] Banjoko, S. A., Iwuji, I. I. \&Bagshaw, K. (2012). "The Performance of the Nigerian Manufacturing Sector: A 52- Year Analysis of Growth and Retrogression (1960-2012)". A Journal of Asian Business Strategy.

[15] Bankole, A. S. (2005). Nigeria's Industrialization Strategy Under Multilateral Trade Agreement. In: The Challenges of Industrialization: A Pathway to Nigeria becoming a Highly Industrialized Country in the Year 2015. Nigerian Economic Society, Ibadan.

[16] Blank, R. (2010). "Selecting among Anti-Poverty Measures, Can an Economist be both Critical and Caring? “, Review of Social Economy.

[17] Busari, D. T. (2005).Foreign Capital, Globalization and the Challenges of Industrialization in Nigeria. In: The Challenges of Industrialization: A Pathway to Nigeria becoming a Highly Industrialized Country in the Year 2015. Nigerian Economic Society, Ibadan.

[18] CBN (2002).The Changing Structure of the Nigerian Economy and Implication for Development. Lagos: Realm Communication Ltd.

[19] CBN (2018).Central bank of Nigeria statistical bulletin, 2(4). 34-44

[20] CBN. (2000). Kano ZonalStatistics.Retrieved from Central Bank of Nigeria.

[21] CBN. (2005). Statistical Bulletin.Retrieved from Central Bank of Nigeria.

[22] Central Bank of Nigeria (2011) Statement of Accounts and Annual Reports. Abuja: Central Bank of Nigeria.

[23] Central Bank of Nigeria. (2008). Central Bank of Nigeria Statistical Bulletin, Vol. 19.

[24] Central Bank of Nigeria. (2010). Central Bank of Nigeria Statistical Bulletin Vol. 21.

[25] Central Bank of Nigeria. (2011). Central Bank of Nigeria Statistical Bulletin, Vol.22.

[26] Central Bank of Nigeria. (2013). Central Bank of Nigeria Statistical Bulletin, Vol. 24

[27] Central Bank of Nigeria.(2006). Central Bank of Nigeria Statistical Bulletin, Vol.17.

[28] Central Bank of Nigeria.(2009). Central Bank of Nigeria Statistical Bulletin, Vol. 20.

[29] Central Bank of Nigeria.(2012). Central Bank of Nigeria Statistical Bulletin, Vol. 23.

[30] Daibi, W. G. (2014). Nigerian Industrial Development between 1943 and 2013: Challenges and Opportunities, International Review of Research in emerging Markets and the Global Economy (IRREM) An Online International Research Journal (ISSN: 2311-3200) Vol 1 Issue 3.

[31] Dare-Ajayi, D. (2007), Recent Trends an Patterns in Nigeria's Industrial Development, Africa Development, XXXII, 139 -155.

[32] Davis, E. P. (2007). A Confrontation of Economic and Theological Approach to "Ending Poverty in Africa" Working Paper, Brunel University and London School of Theology.

[33] De Beer, F. \&Swanpoel, H. (2000).Introduction to Development Studies.

[34] De Long, J. \& Lawrence, H. S. (1991). “Equipment Investment and Economic Growth “, Quarterly Journal of Economics.

[35] Dorado, M. P \&Smith, S. C. (2003).Economic Development. $8^{\text {th }}$ Edition, Delhi: Lesson Edition (Singapore) Pte Ltd. Indiana Branch.

[36] Duru, M., (2012), New Challenges for Industrial Policy in Nigeria, Universal Journal of Management and Social Sciences.Vol.2, No 7.

[37] Egwaikhide, F. O (1997). Import Substitution Industrialization in Nigeria: A Selected Review. Nigeria Journal of Economic and Social Studies.

[38] Egwaikhide, F. O., Ekpo, A. H., Oyeranti, O. \&Ayodele, o. (2001). Four Decades of Industrialization in Nigeria: A Critical Analysis. Nigeria Journal of Economics and Social Studies.

[39] Ekpo, A. H. (2005). Industrialization and Nigeria's Economic Development. In: The Challenges of Industrialization: A Pathway of Nigeria Becoming a Highly Industrialized Country in the Year 2015 Nigerian Economic Society, Ibadan.

[40] Ekpo, A. H. (2005). Industrialization and Nigeria's Economic Development. In: The Challenges of Industrialization: A Pathway of Nigeria Becoming a Highly Industrialized Country in the Year 2015, Nigerian Economic Society, Ibadan.

[41] Ekpo, A. H. (2015). Industrialization and Nigeria's Economic Development in: The Challenges of Industrialization: A Pathway of Nigeria becoming a Highly Industrialized Country in the Year 2015, Nigerian Economic Society, Ibadan

[42] Englama, A.; Duke, O.; Ogunleye, T. and Isma'il, F. (2010) Oil Prices and Exchange Rate Volatility in Nigeria: An Empirical Investigation.Central Bank of Nigeria Economic and Financial Review.Vol.48/3 September. 
[43] Essia, U \&Ibor, U. E. (2005).Industrialization and Import Addition in Nigeria- A Keynesian-Structuralist Perspective. In: The Challenges of Industrialization: A Pathway to Nigeria becoming a Highly Industrialized Country in the Year 2015 Nigerian Economic Society, Ibadan.

[44] Essien, E. B. (2004). Development and Sustaining Indigenous Technology for Sustainable Industrialization in Nigeria. In: The Challenges of Industrialization: A Pathway to Nigeria becoming a Highly Industrialized Country in the Year 2015, Nigeria Economic Society Ibadan.

[45] Eviews 10 user guide. California: HIS global incorporated.

[46] Ewubare, D. \&Okpanni, A. (2018).International Journal of Advanced Studies in Ecology, Development and Sustainability| IJASEDS ISSN.

[47] Ezekiel, O (2013): Agricultural Development. Optimising the Value Chain.Bank of Industry, Lagos, Nigeria.

[48] Federal Ministry of Industries (1988), Industrial Policy of Nigeria: Policies, Incentives, Guidelines and Institutional Framework, Abuja: Federal Ministry of Industries.

[49] Federal Ministry of Industry \& Technology (FMI\&T) (1992), Industrialization in Nigeria: A Handbook, Ikeja: Sahel Publishing \& Printing Co.

[50] Federal Ministry of Information (FMI) (1970), Second National Development Plan 1970 - 1974, Lagos: Government Printer.

[51] Federal Republic of Nigeria (FRN) (1986), Structural Adjustment Programme for Nigeria, July 1986 June 1988, Lagos: Government Printer.

[52] FGN (1970). Second National Development Plan, 1970-1975, Lagos, Central Planning Office.

[53] Foreman-Peck, J. \&Fedrico, G. (1999). European Industrial Policy: The Twentieth Century Experience, Oxford: Oxford University Press.

[54] Galbraith, J. K. (1958). The Affluent Society. Boston: Houghton Mifflin. Kristina Froberg.

[55] Gans, H.)1973). “The Positive Function of Poverty “, American Journal of Sociology.

[56] Geiliches, Z. (1988). "Productivity Puzzles and R\&D: Another non Explanation “, Journal of Economic Perspectives, Fall.

[57] Granger, C. W. J. (1969).Investigating causal relation by econometric and cross-sectional method.Econometrica, 37, 424-438.

[58] Griliches, Z. (1988). "Research Cost and Social Returns: Hybrid Corn and Related Innovations ", Journal of Political Economy.

[59] Gujarati, D.N. (1995).Basic econometrics.Third Editions, MacGraw-Hill.

[60] Gylych, J. \&Enwerem, H. I. (2016).Impact of Industrialization on Economic Growth; Experience of Ten Countries of ECOWAS.Conference Paper on Social Science \& Law, Africa, at Abuja/Nigeria.

[61] Hellenier, G. K. (1972). International Trade and Economic Development, England Harmonds Worth.

[62] Helpman, E. (1991). Innovation and Growth in the Global Economy. Cambridge: MIT Press.

[63] Hills, J., Stewart, K. (2005).“A More Equal Society? New Labour, Poverty, Inequality and Exclusion” (First Ed.) Bristol, United Kingdom: The Policy Press.

[64] Ikpeze, N., Soludo, C., and Elekwa, N. (2004), Nigeria: The Political Economy of the Policy Process, Policy Choice Implementation in C. Soludo, O. Ogbu and H. Chang (eds.), The International Review of Research in Emerging Markets and the Global Economy (IRREM) An Online International Research Journal (ISSN: 2311-3200) 2014 Vol: 1

[65] Isiksal, A. Z. \&Chimezie, O. J. (2016). Impact of Industrialization in Nigeria: European Scientific Journal.

[66] Iwuagwu, O. (2011). The Cluster Concept: Will Nigeria's New Industrial Development JumpStart the Country's Industrial Takeoff? Afro Asian Journal of Social Science, Vol. 2, No 2.4 Qtr IV 2001.

[67] Iwuagwu, O., (2011), The Cluster Concept: Will Nigeria’s New Industrial Development Strategy Jumpstart the Country's Industrial Takeoff? Afro Asian Journal of $\quad$ Social Sciences, Vol.2 No 2.4 Qtr IV 2011.

[68] Johansen, S. (1988). Statistical analysis of cointegration vectors, Journal of Economic Dynamics and Control, 12(2/3): 231-254.

[69] Johansen, S., \&Juselius, K. (1990).Maximum likelihood estimation and inference on cointegration with applications to the demand for money.Oxford Bulletin of Economics and Statistics, 52, 169-210

[70] Jung, S. Y. \& Smith, R. (2007).“The Economics of Poverty: Explanatory Theories to Inform Practice “, Journal of Human Behaviour in the Social Environment.

[71] Kaldor, N. 1967.Strategic Factors in Economic Development. New York: W.F. Humphrey Press.

[72] Kayode, M.O. and O. Teriba (1977).Industrial Development in Nigeria. Ibadan: University Press. 
[73] Kirk-Greene, A. \&Rimmer, D. (1981), Nigeria since 1970: A Political \& Economic Outline, London: Hodder\& Stoughton.

[74] Kirkpatrick, C. H., Lee, N. \&Nixson, F. I. (1984).Industrial Structure and Police in Less Developed Countries. Hamel Hempstead, United Kingdom, George Allen \&Unwin (Publishers) Ltd.

[75] Kolawole, B. \&Omobitan, A. (2015). Poverty, Inequality and Growth in Nigeria: An Empirical Evidence, Department of Economics, Faculty of Social Sciences, Lagos State University, Ojo, Lagos.

[76] Laderchi, C. R., Saith, R. \& Stewart, F. (2003). "Does it Matter that we do not agree on the definition of Poverty? A Comparison of Four Approaches “, Oxford Develop Studies, Volume 31, Issue 3

[77] Lewis, o. (1965). “The Children of Sanchez “, Penguin, Harmonds Worth.

[78] Lucas, R. (1988). “On the Mechanism of Economic Development”, Journal of Monetary Economics.

[79] Mike, D. (2012). "New Challenges for Industrial Policy in Nigeria “. Universal Journal of Management and Social Studies Vol. 2

[80] Muhammad, M. (2011). Globalization Crisis and National Security: A Reflection on Nigeria Textile Industry. Journal of Research in National Development, 9 (1),

[81] Narayan, D. (2000). Poverty is Powerlessness and Voicelessness, IMF Finance and Development Vol. 37, No. 4.

[82] National Bureau of Statistics (2015). Nigerian Mining and Quarrying Sector: Summary Report 2010-2012.

[83] National Bureau of Statistics (NBS, 2018). Data on Nigerian macroeconomic variables, 2(1).67b

[84] National Union of Textile, Garment and Tailoring Workers (2005). Paper presented at the 4 days Educational Conference Abuja

[85] Ndebbio, J. U. (1994). Industrial Development Policies/Incentives and Their Impact on the Nigerian Economy. In: Ndebbio and Ekpo (eds.). The Nigerian Economy at Crossroads: Policies and Their Effectiveness. Calabar, University of Calabar Press.

[86] Ndiyo, N. A \&Ebong, F. S. (2003). The Challenges of Openness in Developing Economics: Some Empirical Lesson from Nigeria, Selected Paper for 2013 Annual Conference of the Nigerian Economic Society.

[87] Nigerian Textile Manufacturing Association (2009).Nigerian Textile Manufacturers Association Competitiveness Assessment on Several Performance Indicators, Lagos.

[88] Nolan, B. \& Marx, I. (2009). "Economic Inequality, Poverty and Social Exclusion “, In eds. W Salverda, B Nolan and Smeeding, the Oxford Handbook of Economic Inequality ", Oxford University Press.

[89] Nworgu B.G. (1991). Educational research: Basic issues and methodology. Ibadan: Wisdom Publisher ltd.

[90] Obioma, E. \&Ozugjalu, U. (2005). Industrial and Economic Development: A Review of Major Conceptual and Theoretical Issues in: The Challenges of Industrialization: A Pathway to Nigeria Becoming a Highly Industrialized in the Year 2015, Niger Economic Society, Ibadan.

[91] Ogbeide, O., Nwamaka, E. \&Agu, D. (2005). Asians Economic and Financial Review: Poverty and Inequality in Nigeria.

[92] Ogbu, O. (2012). Towards Inclusive Growth in Nigeria.The Brookings Institution's Global Economic and Development Policy Paper.No. 2012-03, June.

[93] Ogunrinola, I. O. \&Osabuohien, E. S. (2010).Globalization in Nigeria's Manufacturing Sector.The European Journal of Social Sciences.

[94] Ollor, W G., (2008), Adjustment without Financing, Essays on Nigerian Structural Adjustment Programme, Port Harcourt: Hellor Consult.

[95] Onyemelukwe, J. O. C (1983), Structural and Locational Characteristics of Manufacturing, in J S Oguntoyinbo, O O Areola, M Filani., A geography of Nigerian Development 2nd ed., Ibadan: Heinemann Edu. Books.

[96] OPS (2001).Organized Private Sector Year 2001 Pre-Budget Memorandum to the Federal Government. October 25.

[97] Romer, P. (1986). “Increasing Returns and Long Run Growth “, Journal of Political Economy.

[98] Rosebery, N. (1976). Perspective on Technology. Cambridge, UK: Cambridge University Press.

[99] Sachs, J. (2005). “The End of Poverty “, London: Penguin.

[100]Samuelson, P. (1955). “A Diagrammatic Exposition of a Theory of Public Expenditure “, Review of Economics and Statistics.

[101] Sanusi, J. (2003) Overview of Government's Efforts in the Development of SMEs and the Emergence of SMEEIS, www.cenbank.org

[102]Sen, A. (1999). “Development as Freedom “, Oxford University Press, New York. 
[103]Uniamikogbo, S. O. (1996). Nigeria's Non-Oil Export Sector: An Analysis of Some Issues for Consideration beyond Adjustment. The Nigeria Journal of Economics and Social Studies.

[104]UNIDO. (2003). Industrial Development Review Series.

[105]United Nations (2008). "Human Development Report 2007/8", New York, United Nations.

[106]United Nations Development Program (2003). "Human Development Report 2002", Available at hdr.undo.org/reports/global/2002

\section{APPENDICES}

\section{Trend Analysis}

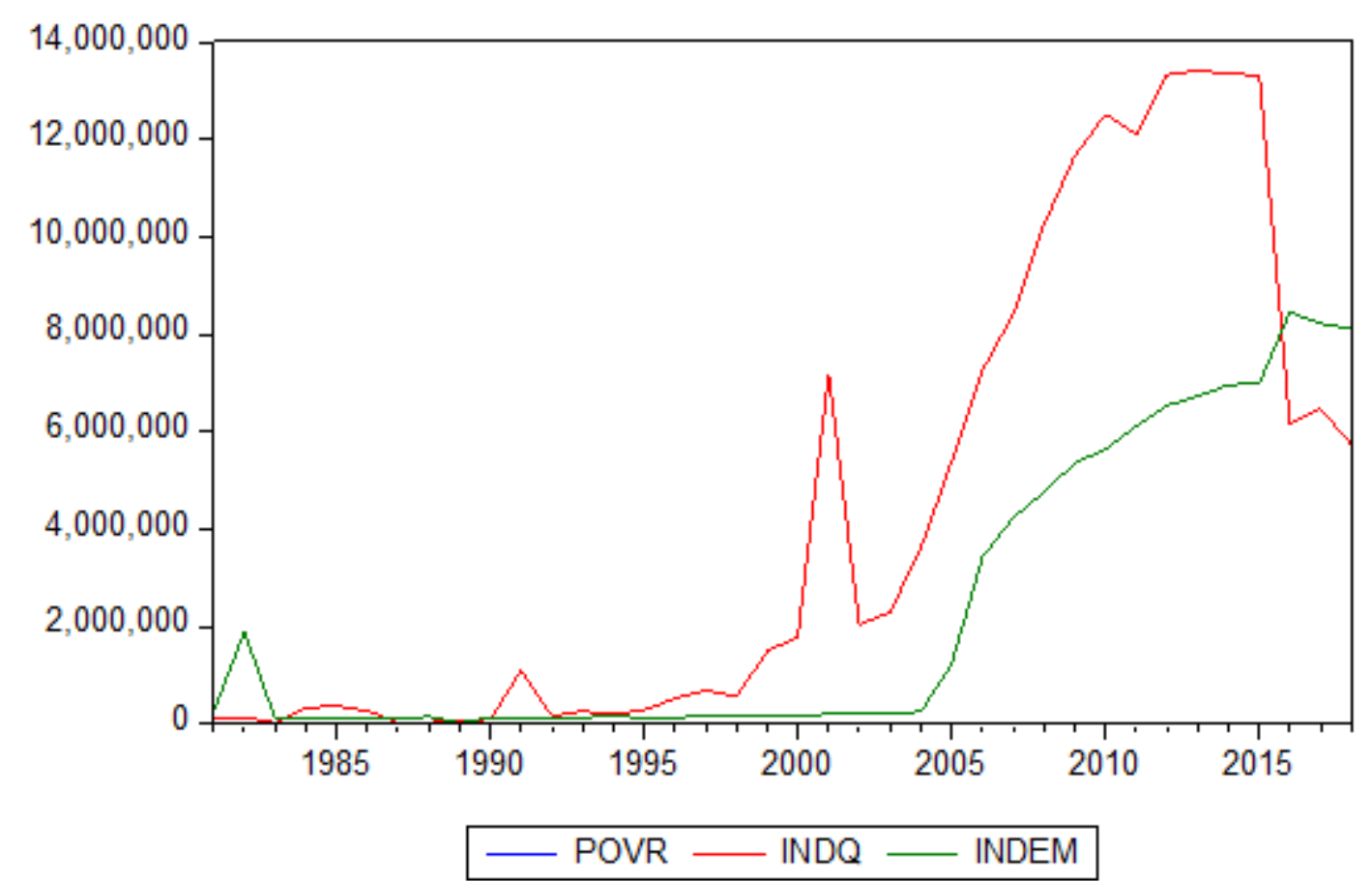

Figure1. The trend of poverty rate (POVR), aggregate industrial output (INDQ) and aggregate industrial employment (INDEM) in Nigeria from1981-2018.

Source: Computed with e-views 10 by the researcher (2020)

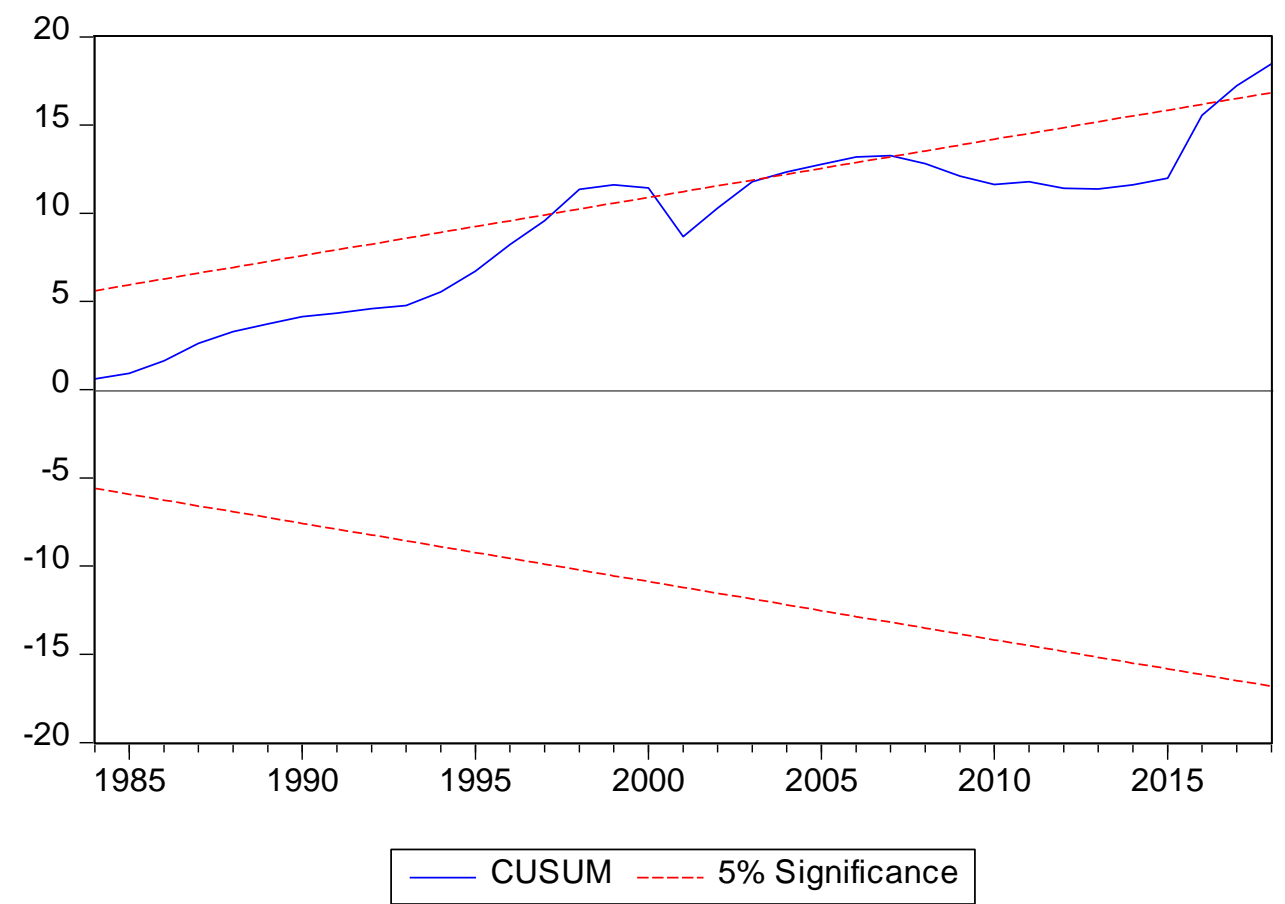

2. Data on Poverty Rate (POVR), Aggregate Industrial output (INDQ) and Aggregate Industrial Employment (INDEM) 
Industrial Sector Performance and Poverty Reduction in Nigeria: 1981-2018

\begin{tabular}{|c|c|c|c|}
\hline YEAR & POVR \% & INDQ \#billion & INDEM Million \\
\hline 1981 & 27 & 118028.02 & 256623 \\
\hline 1982 & 30 & 124490.22 & 1884438 \\
\hline 1983 & 34 & 30681.63 & 106496 \\
\hline 1984 & 37 & 329648.11 & 112588 \\
\hline 1985 & 41 & 370466.09 & 121345 \\
\hline 1986 & 44.2 & 262446.83 & 97234 \\
\hline 1987 & 44 & 26662 & 85634 \\
\hline 1988 & 44 & 31022.2 & 145610 \\
\hline 1989 & 44 & 63546.8 & 16453 \\
\hline 1990 & 43.9 & 95226.3 & 133675 \\
\hline 1991 & 43.8 & 1100833 & 111654 \\
\hline 1992 & 43 & 160043 & 100235 \\
\hline 1993 & 42.5 & 258474.5 & 123564 \\
\hline 1994 & 48 & 191349.1 & 187564 \\
\hline 1995 & 53.9 & 289121.3 & 102345 \\
\hline 1996 & 59 & 511777.12 & 123564 \\
\hline 1997 & 61 & 690414.2 & 184373 \\
\hline 1998 & 66 & 553527.4 & 163264 \\
\hline 1999 & 68 & 1493803.6 & 184239 \\
\hline 2000 & 69 & 1791198.9 & 169846 \\
\hline 2001 & 70 & 7199648.5 & 194576 \\
\hline 2002 & 71 & 2031692.1 & 213456 \\
\hline 2003 & 72 & 2291291.3 & 234568 \\
\hline 2004 & 71 & 3616837 & 245678 \\
\hline 2005 & 73.4 & 5391199 & 1234567 \\
\hline 2006 & 73 & 7267963.7 & 3432564 \\
\hline 2007 & 74 & 8404310 & 4231674 \\
\hline 2008 & 76 & 10266548 & 4765432 \\
\hline 2009 & 75.8 & 11664532.8 & 5347865 \\
\hline 2010 & 79 & 12525329.9 & 5647812 \\
\hline 2011 & 79 & 12112951.1 & 6113479 \\
\hline 2012 & 78 & 13333837.4 & 6534986 \\
\hline 2013 & 80 & 13431421.4 & 6733389 \\
\hline 2014 & 81 & 13351143.5 & 6964353 \\
\hline 2015 & 82.5 & 13338639.4 & 7002349 \\
\hline 2016 & 85 & 6174796.82 & 8456349 \\
\hline 2017 & 84.6 & 6476346.63 & 8221654 \\
\hline 2018 & 83.9 & 5733172.53 & 8115432 \\
\hline
\end{tabular}

Source: Central Bank of Nigeria (CBN, 2018) National Statistics (NBS, 2018)

Citation: Eneji Mathias Agri, et.al. "Industrial Sector Performance and Poverty Reduction in Nigeria: 19812018" International Journal of Managerial Studies and Research (IJMSR), vol 8, no. 12, 2020, pp. 64-79. doi: https://doi.org/10.20431/2349-0349.0812007.

Copyright: (c) 2020 Authors. This is an open-access article distributed under the terms of the Creative Commons Attribution License, which permits unrestricted use, distribution, and reproduction in any medium, provided the original author and source are credited. 